Revista Brasileira de Farmacognosia Brazilian Journal of Pharmacognosy 22(4): 724-729, Jul./Aug. 2012

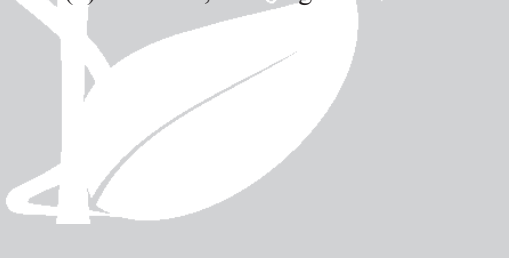

Article

Received 26 Dec 2011

Accepted 28 Jan 2012

Available online 15 May 2012

Keywords:

Gracilaria domingensis

Gracilaria birdiae

Rhodophyta

Carotenoids

antioxidant activity

fatty acids
ISSN 0102-695X

http://dx.doi.org/10.1590/S0102-

$695 \times 2012005000063$

\section{Antioxidant activity and chemical composition of the non polar fraction of Gracilaria domingensis (Kützing) Sonder ex Dickie and Gracilaria birdiae (Plastino \& Oliveira)}

\author{
Thais Guaratini, ${ }^{1}$ Norberto P. Lopes, ${ }^{2}$ Eliane Marinho-Soriano, ${ }^{3}$ \\ Pio Colepicolo, ${ }^{1}$ Ernani Pinto ${ }^{4 *}$
}

\begin{abstract}
${ }^{1}$ Departamento de Bioquímica, Instituto de Química de São Paulo, Universidade de São Paulo, Brazil.

${ }^{2}$ Departamento de Física e Química, Faculdade de Ciências Farmacêuticas de Ribeirão Preto, Universidade de São Paulo, Ribeirão Preto-SP, Brazil,

${ }^{3}$ Departamento de Oceanografia e Limnologia, Universidade Federal do Rio Grande do Norte, Brazil,

${ }^{4}$ Departamento de Análises Clínicas e Toxicológicas, Faculdade de Ciências Farmacêuticas Universidade de São Paulo, Brazil.
\end{abstract}

\begin{abstract}
Gracilaria domingensis (Kützing) Sonder ex Dickie and Gracilaria birdiae (Plastino \& Oliveira) (Gracilariales, Rhodophyta) are seaweeds that occur on the Brazilian coast. Based on their economic and pharmaceutical importance, we investigated the antioxidant activity of the methanolic, ethyl acetate and hexane extracts of both species. The hexane extracts display a high antioxidant activity and comparative analyses indicated $G$. birdiae as the most active species. Chemical investigation of these fractions showed several carotenoids and fatty acids, as well as cholesterol and sitosterol derivatives. HPLC-DAD analysis of G. birdiae showed violaxanthin (0.04 $\mu \mathrm{g} . \mathrm{mg}^{-1}$ of dry material), antheraxanthin $\left(5.31 \mu \mathrm{g} \cdot \mathrm{mg}^{-1}\right)$, aloxanthin $\left(0.09 \mu \mathrm{g} . \mathrm{mg}^{-1}\right)$, zeaxanthin $\left(0.45 \mu \mathrm{g} . \mathrm{mg}^{-1}\right)$ and $\beta$-carotene $\left(0.37 \mu \mathrm{g} . \mathrm{mg}^{-1}\right)$ as the major carotenoids. $G$. domingensis showed a similar carotenoid profile, however, with much lower concentration than G. birdiae. Gas chromatography coupled to mass spectrometry was used to determine other nonpolar compounds of these seaweeds. The main compounds detected in both studied species were the fatty acids $16: 0 ; 18: 1 \Delta^{9} ; 20: 3 \Delta^{6,9,12}, 20: 4$ $\Delta^{5,8,11,14}$. We found no specificity of compounds in either species. However, G. birdiae, presented higher contents of carotenoids and arachidonic acid than $G$. domingensis.
\end{abstract}

\section{Introduction}

Seaweeds have been used in traditional medicine for centuries and some genera, including Gracilaria, present species that are economically important since they are used in the pharmaceutical, nutraceutical, cosmetic and food industries (Blouin et al., 2011; Gressler et al., 2010, Holdt \& Kraan, 2011). Fresh and dried seaweeds are extensively commercialized because they are rich in proteins, fatty acids, vitamins, and minerals (Cardozo et al., 2007; Fayaz et al., 2005; Gressler et al., 2011). As described for plants, nutrient and chemical composition of seaweeds may vary due to species, temperature oscillation and geographic area (Cardozo et al., 2007; Gobbo-Neto \& Lopes, 2007, 2008).

Previous work applied simultaneous fluorescence and $\mathrm{O}_{2}$ evolution experiments for calculation of the percentage of carotenoids in $G$. domingensis and G. birdiae (Andersson et al., 2006). The comparison suggested a lower content of carotenoids in $G$. domingensis compared to G. birdiae. Gracilaria is economically important for agar production in Brazil; however, there is little quantitative information on the individual carotenoids and the fatty acid composition of these two species (Carnicas et al., 1999; Guaratini et al., 2005; Guaratini et al., 2007; Pinto et al., 2011). Valuable products extracted from algae have been studied at different levels (Pinto et al., 2003; Cardozo et al., 2008).

Regarding natural products produced by macroalgae and the correlation with environmental conditions, sensitive analytical procedures for the separation, identification and quantification of the major metabolites in apolar and polar extracts are needed for 
more detailed analyses and future studies. In the present study, we employ HPLC-DAD and GC-MS for the analyses of the carotenoid and fatty acid contents in two wild Gracilaria species ( $G$. domingensis and $G$. birdiae) that occur in Brazil. A comparison of the antioxidant activities of hexane and ethyl acetate extracts of $G$. domingensis and $G$. birdiae was also carried out.

\section{Materials and Methods}

\section{Chemicals}

All solvents were HPLC or reagent grade, from Sigma Chemical Company (St. Louis, MO, USA), Tedia (São Paulo, Brazil) and Mallinckrodt (Paris, KY, USA). Deionized water was obtained using a Milli-Q water purification system (Millipore, Bedford, MA, USA). Stock solutions of antheraxanthin $\left(0.625 \mathrm{mg} \mathrm{L}^{-1}\right)$, lutein $\left(1.296 \mathrm{mg} \mathrm{L}^{-1}\right)$, violaxanthin $\left(0.814 \mathrm{mg} \mathrm{L}^{-1}\right)$, and zeaxanthin $\left(0.591 \mathrm{mg} \mathrm{L}^{-1}\right)$ in ethanol were purchased from DHI Water \& Environment (Copenhagen, Denmark) and stored at $-80^{\circ} \mathrm{C}$. $\beta$-Carotene, astaxanthin and chlorophyll $a$ and $b$ were purchased from Sigma (St. Louis, USA).

\section{Algae material}

Gracilaria domingensis (Kützing) Sonder ex Dickie (Gracilariales, Rhodophyta) and Gracilaria birdiae Plastino \& Oliveira (Gracilariales, Rhodophyta) were collected at Praia do Cotovelo in Natal, Brazil (5 $\left.55^{\prime} 33.6^{\prime \prime} \mathrm{N}-35^{\circ} 9^{\prime} 14.4^{\prime \prime} \mathrm{W}\right)$, and stored at $-80^{\circ} \mathrm{C}$ until extraction. Voucher samples were collected by Prof. Dr. Eliane Marinho-Soriano, Federal University of Rio Grande do Norte, RN.

\section{Antioxidant activity}

DPPH (1,1-diphenyl-2-picrylhydrazyl) solution were prepared in methanol, as previously published (Yokozawa et al., 1998; Pellat et al., 2004). In a 96well microplate, $10 \mu \mathrm{L}$ of a $1 \mathrm{mM}$ solution of DPPH and appropriate volumes of antioxidant (to obtain final concentrations of $0.1,0.5,1.0,1.5$ and $2.0 \mathrm{mg} / \mathrm{mL}$ ) were added and the final volume of $100 \mu \mathrm{L}$ completed with methanol. For each concentration of the antioxidant, corrections were made for the absorbance of the reference (samples without DPPH solution) and comparisons made to the rate in the absence of any added antioxidant (negative control). After preparation, samples were placed in an Elisa reader at $25^{\circ} \mathrm{C}$ in the dark. The samples were incubated for different time intervals (10 to $130 \mathrm{~min}$ with 10-min intervals) and then standardized to the same reaction time for all extracts. Triplicates were performed for each concentration and the readings were made at 517 nm (Pellati et al., 2004; Yokozawa et al., 1998).
For the peroxidation assay, linolenic acid micelles were prepared with $2.6 \mathrm{mM}$ of sodium dodecyl sulfate (SDS) in $0.01 \mathrm{M}$ sodium phosphate buffer, $\mathrm{pH}$ 7.4. An aliquot of $10 \mu \mathrm{L}$ of methanol solution of the antioxidant to be tested at different concentrations was added to $2 \mathrm{~mL}$ of lipid suspension in a quartz cuvette. After $10 \mathrm{~min}$ incubation at $50{ }^{\circ} \mathrm{C}$, lipid peroxidation was initiated with $10 \mu \mathrm{L}$ of $0.07 \mathrm{M}$ 2,2'-azobis(2amidinopropane) (ABAP), also prepared in phosphate buffer. The kinetics of formation of lipoperoxides was accompanied spectrophotometrically at $234 \mathrm{~nm}$ for 15 min (Chicaro et al., 2004).

\section{Preparation of samples for HPLC analysis}

The samples were prepared as previously published (Guaratini et al., 2009). In resume, the homogeneous, freeze-dried samples were weighed, dissolved in methanol:acetone $(1: 1, \mathrm{v}: \mathrm{v})$ and sonicated for $15 \mathrm{~min}$. The extracts were then centrifuged and filtered through a $0.45 \mu \mathrm{m}$ membrane (Millex HN nylon, $13 \mathrm{~mm}$, Millipore). Aliquots $(50 \mu \mathrm{L})$ of the extract $(3 \mathrm{mg}$ $\left.\mathrm{mL}^{-1}\right)$ were injected into the HPLC system. The pigment content was expressed as $\mu \mathrm{g}$ per mg of dry weight $(\mu \mathrm{g}$ $\mathrm{mg}^{-1} \mathrm{DW}$ ).

\section{HPLC equipment}

The HPLC instrument consists of a Shimadzu SCL-10A $V P$ system equipped with two LC-10AD pumps, a SIL-10ADVP automatic sample injector, a DGU-14A degasser, and a SPD-M10AVP photodiodearray detector. The Coulochem III ED electrochemical detector (ESA Inc., Chelmsford, MA), coupled in series with the photodiode-array detector, consisted of a guard cell (Model 5021) and an analytical cell (Model 5010) with two porous graphite working electrodes, palladium reference electrodes and platinum counter electrodes.

The analyses were carried out as previous reported (Guaratini et al., 2009). Chromatographic separations were carried out on a $\mathrm{C}_{30}$ column (Ultracarb, 250 x 4.6

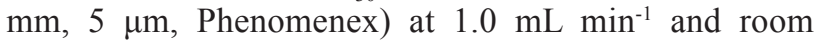
temperature, using as mobile phase: (A) methanol:water:1 $\mathrm{M}$ ammonium acetate buffer, $\mathrm{pH} 4.6$ (90:8:2), and (B) methanol:methyl-tert-butyl ether (MTBE):1 M ammonium acetate buffer, pH 4.6 (30:68:2). The gradient elution was performed as follows: a linear increase from 5 to $10 \%$ of solvent B (0-15 min); maintaining $10 \% \mathrm{~B}$ for $10 \mathrm{~min}$; a linear gradient (10 min) to $15 \% \mathrm{~B}$ followed by another linear gradient ( $5 \mathrm{~min}$ ) to $40 \% \mathrm{~B}$ and then an increase to $45 \%$ of solvent $\mathrm{B}$ in $2 \mathrm{~min}$, an isocratic elution for $20 \mathrm{~min}$ and an increase to $100 \% \mathrm{~B}$ in $1 \mathrm{~min}$ and maintaining $100 \% \mathrm{~B}$ for $5 \mathrm{~min}$, for a total run time of $68 \mathrm{~min}$. The chromatographic parameters, capacity factors $(k)$ and separation factors $(\alpha)$ were calculated to 
evaluate the separation efficiency. The injection volume of standards and samples was $50 \mu \mathrm{L}$ and all ultravioletvisible spectra were recorded from 200 to $800 \mathrm{~nm}$. For quantitative analyses, chromatograms were integrated at $445 \mathrm{~nm}$. The ED was operated in the DC-mode and the settings were as follows: $+850 \mathrm{mV}$ at the guard channel (to improve the baseline signal by oxidizing interfering compounds possibly present in the mobile phase) and $+600 \mathrm{mV}$ at the first cell (channel 1). For confection of the hydrodynamic voltammograms, data were acquired in channel 1, which was set at different potentials in each run $(+100$ to $+900 \mathrm{mV}$, in $50 \mathrm{mV}$ increments).

\section{Preparation of samples for CG-MS analysis}

Ten milliliters $(10 \mathrm{~mL})$ of dichloromethane (J.T.Baker, Phillipsburg, NJ, USA) were added to 1.0 $\mathrm{g}$ (DW) of each evaporated hexane extract of algae and submitted to an ultrasonic bath for $30 \mathrm{~min}$ followed by filtration. Subsequently, $2.0 \mathrm{~mL}$ of $1.0 \mathrm{M}$ sodium methoxide were added to the extract and shaken occasionally during $5 \mathrm{~min}$ at $65^{\circ} \mathrm{C}$. After cooling, 1.0 $\mathrm{mL}$ of water was added and the mixture was extracted with $1.0 \mathrm{~mL}$ of chloroform (J.T.Baker, Phillipsburg, NJ, USA) by shaking for one minute and centrifuging at 3,000 rpm to extract methyl esters of the fatty acids. The chloroform extraction was further repeated two times. The chloroform phases were combined $(3.0 \mathrm{~mL})$ and the solvent evaporated under a flow of nitrogen gas. Samples were suspended in $1.0 \mathrm{~mL}$ of ethyl acetate (J.T.Baker, Phillipsburg, NJ, USA), dried with anhydrous sodium sulfate (Sigma Inc., St. Louis, MO, USA).

\section{GC-MS analysis}

Samples were analyzed by GC-MS with a Shimadzu QP2010 with ionization source of $70 \mathrm{eV}$ and fragmentation by electron impact (EI). Samples of $1.0 \mu \mathrm{L}$ of each sample were injected at $220{ }^{\circ} \mathrm{C}$ on a DBWAX column $(30 \mathrm{~m} \times 0.25 \mathrm{~mm} \times 0.25 \mu \mathrm{m})$. The analysis occurred in the splitless mode, with 1 min sample time, a column flow of $1.3 \mathrm{~mL} \mathrm{~min}^{-1}$, a linear velocity of $41.4 \mathrm{~cm} \mathrm{~s}^{-1}$ and scan between $\mathrm{m} / \mathrm{z} 40$ and $\mathrm{m} / \mathrm{z} 500$. The oven temperature started at $50^{\circ} \mathrm{C}$, was increased at $20^{\circ} \mathrm{C} \cdot \mathrm{min}^{-1}$ to $200{ }^{\circ} \mathrm{C}$, kept at this temperature for $5 \mathrm{~min}$, then increased at 5 ${ }^{\circ} \mathrm{C} \min ^{-1}$ to $230{ }^{\circ} \mathrm{C}$ and kept at this temperature for 30 min. For identification of the compounds, the peaks were compared with standards, when available, always consulting the WILEY7 library.

\section{Results and Discussion}

The DPPH system generate a stable free radical and is often used in preliminary studies, mainly for screening extracts to indicate antioxidant capacity. This procedure is fast and, at the same time, sensitive (Yokozawa et al., 1998). Hydrogen donor molecules present in the extract that react with the DPPH radical cause a decrease in the intensity of absorption at 517 $\mathrm{nm}$ and can help identify extracts with anti-radical compounds. This reaction is dependent on exposure and, after a time course analysis, we established a reaction time of $30 \mathrm{~min}$ to test all extracts and determine the IC30 and IC50 values (minimum inhibitory concentration of 30 or $50 \%$ of the radical, respectively) (results are presented in Table 1). G. birdiae extracts showed better results. The hexane fractions from $G$. birdiae required approximately $0.6 \mathrm{mg} \cdot \mathrm{mL}^{-1}$ and $0.8 \mathrm{mg} \cdot \mathrm{mL}^{-1}$ extract for $50 \%$ inhibition of DPPH radical. An additional lipid peroxidation assay was carried out to confirm the antioxidant activity. Lipid peroxidation is initiated by any species capable of abstracting a hydrogen atom from the lipid methylene groups (Gutteridge \& Halliwell, 1990). The method used in this work used micelles of linolenic acid in buffer and SDS. The linolenic acid in the micelles reacts with the radical initiator ABAP and the procedure measures the kinetics of lipoperoxide formation. When antioxidants are included in this system, there is a consequent reduction in the formation of lipoperoxides and, therefore, the rate of reaction (Chicaro et al., 2004) decreases. The initial rates of formation of lipoperoxides were plotted versus the concentrations tested for each extract, to obtain a slope value that can be compared to the positive control ( $\alpha$-tocopherol solution). From these data, we determined the relative antioxidant activity of

Table 1. Antioxidant activity of the Gracilaria birdiae and G. domingensis extracts determined from the inhibition of DPPH formation. Data are presented as IC30 and IC50, from five independent experiments.

\begin{tabular}{lcccc}
\hline \multirow{2}{*}{ Extracts } & \multicolumn{3}{c}{ G. birdiae } & \multicolumn{2}{c}{ G. domingensis } \\
\cline { 2 - 5 } & IC30 & IC50 & IC30 & IC50 \\
\hline hexane & 0.387 & 0.610 & $>2.0$ & $>2.0$ \\
hexane:ethyl acetate & 0.486 & 0.833 & $>2.0$ & $>2.0$ \\
ethyl acetate & 0.665 & 1.193 & $>2.0$ & $>2.0$ \\
butanol & 0.372 & 1.466 & 1.432 & $>2.0$ \\
methanol/H2O & $>2.0$ & $>2.0$ & 1.551 & $>2.0$ \\
\hline
\end{tabular}


each extract, compared to the activity of $\alpha$-tocopherol, as presented in Table 2. In these trials, as in the DPPH assay, the highest activities were detected in the more apolar extracts of the alga $G$. birdiae. In previous work, Nahas et al. (2007) also observed a higher activity in the less polar extracts by testing different species of algae, reinforcing our observation.

Table 2. Antioxidant activity of the Gracilaria birdiae and $G$. domingensis extracts by the lipoperoxidation inhibition assay (ABAP).

\begin{tabular}{lcc}
\hline \multicolumn{1}{c}{ Extracts } & G. birdiae & G. domingensis \\
\hline hexane & 3.5 & - \\
hexane:ethyl acetate & 2.4 & 1.3 \\
ethyl acetate & 0.75 & 1.0 \\
butanol & 1.02 & 1.4 \\
methanol/H2O & 0.29 & 0.74 \\
\hline
\end{tabular}

These biological results stimulated the investigation of the apolar extracts (hexane) of both algae. A previously published methodology was applied for the identification and quantification of apolar compounds using co-injection of authentic standards to confirm their presence (Table 3). Overall, the screening analysis and the preliminary chemical profile confirmed the possibility of grouping the hexane fraction with the hexane/acetate fraction of each individual species. The qualitative analysis of the pooled fractions revealed a similar profile with five major carotenoids in each species (see Table 4); however, the level of carotenoids is higher in G. birdiae than in G. domingensis. These results are in agreement with the data obtained of Andersson et al. (2006). Some differences can be explained in terms of biotic and abiotic parameters (Gobbo-Neto \& Lopes, 2007), such as the strains studied, the age and time of collection, and the tissue analyzed. In this case, both species were collected at the same time and place and these data suggest that the variations are more related to the strains studied.

Table 3. Carotenoids identified in Gracilaria birdiae and G. domingensis by HPLC-DAD with authentic standard comparison. Peak number $\left(\mathrm{P}_{\mathrm{n}}\right)$, Retention time $\left(\mathrm{R}_{\mathrm{t}}\right)$, Maximum wavelength $\left(\lambda_{\max }\right)$, Separation Factor $(\alpha)$.

\begin{tabular}{lcccc}
\hline \multicolumn{1}{c}{ Pigments } & $\mathrm{P}_{\mathrm{n}}$ & $\mathrm{R}_{\mathrm{t}}(\min )$ & $\lambda_{\max }(\mathrm{nm})$ & $\alpha$ \\
\hline violaxanthin & 5 & 17.1 & 438 & 7.1 \\
antheraxanthin & 8 & 26.5 & 445 & 11.6 \\
aloxanthin & 9 & 30.5 & 451 & 13.5 \\
zeaxanthin & 12 & 40.1 & 450 & 18.1 \\
cantaxanthin & 13 & 44.8 & 474 & 20.3 \\
$\beta$-carotene & 16 & 66.8 & 451 & 30.8 \\
\hline
\end{tabular}

Finally, GC-MS analyses were carried out to confirm the presence of other antioxidant constituents in the pooled fractions (Table 5). Several previous studies described the composition of these primary metabolites in algae (Apt \& Behrens, 1999; Arendt et al., 2005; Cardozo et al., 2002; Sanina et al., 2004). Although controversial in the literature, fatty acid profiles have been used as a chemotaxonomic tool to identify brown, red and green algae (Dawczynski et al., 2007). A comparative study of algae found the predominance of saturated fatty acids in red algae, while brown algae were richer in unsaturated fatty acids (Sánchez-Machado et al., 2004). In our analysis, we observed a predominance of unsaturated fatty acids with saturated to unsaturated ratios of $1: 4$ and $1: 1$ for G. birdiae and G. domingensis, respectively. Palmitic acid $(\mathrm{C} 16)$ was found as one of the major constituents (10.75\% G. birdiae and $29.98 \%$ G. domingensis), which confirms results in the literature for other red macroalgae (Dawczynski et al., 2007). High levels of arachidonic acid (C20: 4 5,8,11,14 $\Delta$ ), an essential fatty acid that makes up the family of $\omega-6$, have been described for some species of Gracilaria (46 to 62\%) (Khotimchenko, 2005). Of the two species of Gracilaria studied in this work, $G$. birdiae presented this fatty acid in large quantities (52\%), while $G$. domingensis, although collected under the same conditions, contained only $13 \%$. Note also the presence of acids that comprise the family of $\omega-3$ and 9 , some of which are present in relevant quantities, such as oleic acid $(\mathrm{C} 18: 1 \Delta 9)$, which accounts for 12 to $14 \%$ of the total fatty acids analyzed.

Table 4. Carotenoid quantification ( $\mu \mathrm{g}$ of carotenoids/mg of dry algae) in Gracilaria birdiae and G. domingensis by HPLCDAD.

\begin{tabular}{lccc}
\hline \multicolumn{1}{c}{ Pigments } & $\mathrm{P}_{\mathrm{n}}$ & G. birdiae & G. domingensis \\
\hline violaxanthin & 1 & 0.044 & 0.021 \\
antheraxanthin & 2 & - & 0.224 \\
aloxanthin & 3 & 0.09 & 0.01 \\
zeaxanthin & 4 & 0.445 & 0.249 \\
cantaxanthin & 5 & 0.022 & - \\
$\beta$-carotene & 6 & 0.365 & 0.166 \\
\hline
\end{tabular}

The results of the study show that extracts of Brazilian Gracilaria species present antioxidant activity and contain essential fatty acids and carotenoids ( $\beta$-carotene is a precursor of vitamin $A)$; thus, these algae can be considered to be functional foods. This also has implications for the utilization of these species as a source of antioxidants in applications requiring these properties.

\section{Acknowledgements}

This work was supported by FAPESP, CAPES, CNPq, Ministério da Saúde, Ministério de Ciência e Tecnologia, NAP-USP de Biodiversidade Marinha and CNPq-INCT-Redoxoma. 
Antioxidant activity and chemical composition of the non polar fraction of

Table 5. Percentage of apolar constituents from hexane extracts of Gracilaria birdiae and G. domingensis by GC-MS.

\begin{tabular}{|c|c|c|c|}
\hline \multirow{2}{*}{$\mathrm{R}_{\mathrm{t}}$} & \multirow{2}{*}{ Fatty acids } & \multicolumn{2}{|c|}{$\%$} \\
\hline & & G. birdiae & G. domingensis \\
\hline 7.36 & lauric (C12) & 0.13 & nd \\
\hline 8.63 & myristic (C14) & 3.55 & 4.43 \\
\hline 9.45 & pentadecanoic (C15) & 1.03 & 2.68 \\
\hline 10.52 & palmitic (C16) & 10.75 & 29.98 \\
\hline 10.77 & palmitoleic $(\mathrm{C} 16: 1 \Delta 7)$ & 0.18 & 2.88 \\
\hline 10.84 & palmitoleic $(\mathrm{C} 16: 1 \Delta 9)$ & 0.67 & 4.70 \\
\hline 11.04 & palmitoleic $(\mathrm{C} 16: 1 \Delta 11)$ & 0.06 & 2.80 \\
\hline 11.83 & margaric $(\mathrm{C} 17)$ & 0.80 & nd \\
\hline 12.63 & cyclopentane tridecanoic & nd & 9.10 \\
\hline 13.53 & stearic $(\mathrm{C} 18)$ & 1.94 & 1.91 \\
\hline 13.93 & oleic $(\mathrm{C} 18: 1 \Delta 9)$ & 12.88 & 14.00 \\
\hline 14.04 & octadecenoic $(\mathrm{C} 18: 1 \Delta 11)$ & 2.77 & 2.10 \\
\hline 14.27 & octadecenoic $(\mathrm{C} 18: 1 \Delta 13)$ & nd & nd \\
\hline 14.73 & linoleic $(\mathrm{C} 18: 2 \Delta 9,12)$ & 1.43 & nd \\
\hline 15.28 & octadecatrienoic $(\mathrm{C} 18: 3 \Delta 6,9,12)$ & 0.22 & nd \\
\hline 15.87 & linolenic $(\mathrm{C} 18: 3 \Delta 9,12,15)$ & 0.24 & 1.40 \\
\hline 17.03 & eicosanoic (C20) & 0.13 & 0.66 \\
\hline 17.40 & eicosenoic $(C 20: 1 \Delta 11)$ & 0.51 & 0.47 \\
\hline 18.23 & eicosadienoic $(\mathrm{C} 20: 2 \Delta 11,13)$ & 2.16 & 0.82 \\
\hline 18.72 & eicosatrienoic $(\mathrm{C} 20: 3 \Delta 6,9,12)$ & 5.90 & 2.76 \\
\hline 19.17 & arachidonic $(\mathrm{C} 20: 4 \Delta 5,8,11,14)$ & 52.86 & 13.26 \\
\hline 20.48 & eicosapentenoic $(\mathrm{C} 20: 5 \Delta 5,8,11,14,17)$ & 0.31 & 0.39 \\
\hline 20.65 & docosanoic (C22) & 0.38 & 0.27 \\
\hline 21.14 & docosenoic $(\mathrm{C} 22: 1, \Delta 13)$ & 0.11 & 0.58 \\
\hline 23.03 & tricosanoic $(\mathrm{C} 23)$ & 0.22 & nd \\
\hline 25.99 & lignoceric $(\mathrm{C} 24)$ & 0.31 & 0.54 \\
\hline
\end{tabular}

$\boldsymbol{n d}$ : not detected. $\mathrm{R}_{\mathrm{t}}$ is retention time

\section{References}

Andersson M, Schubert H, Pedersén M, Snoeijs P 2006. Different patterns of carotenoid composition and photosynthesis acclimation in two tropical red algae. Mar Biol 149: 653-665.

Apt KE, Behrens PW 1999. Commercial developments in microalgal biotechnology. J Phycol 35: 215-226.

Arendt KE, Jónasdóttir SH, Hansen PJ, Gärtner S 2005. Effects of dietary fatty acids on the reproductive success of the calanoid copepod Temora longicornis. Mar Biol 146: 513-530.

Blouin NA, Brodie JA, Grossman AC, Xu P, Brawley SH 2011. Porphyra: a marine crop shaped by stress. Trends Plant Sci 16: 29-37.

Cardozo KHM, Oliveira MAL, Tavares MFM, Colepicolo P, Pinto E 2002. Daily oscillation of fatty acids and malondialdehyde in the Dinoflagellate Lingulodinium polyedrum. Biol Rhythm Res 33: 371-382.

Cardozo KHM, Guaratini T, Barros MP, Falcao VR, Tonon AP, Lopes NP, Campos S, Torres MA, Souza AO, Colepicolo P, Pinto E 2007. Metabolites from algae with economical impact. Comp Biochem Physiol Part C: Toxicol Pharmacol 146: 60-78.

Cardozo KHM, Vessecchi R, Carvalho VM, Pinto E, Gates PJ, Colepicolo P, Galembeck SE, Lopes NP 2008. A theoretical and mass spectrometry study of the fragmentation of mycosporine-like amino acids. Int $J$ Mass Spectrom 273: 11-19

Carnicas E, Jimenez C, Niell FX 1999. Effects of changes of irradiance on the pigment composition of Gracilaria tenuistipitata var. liui Zhang et Xia. $J$ Photochem Photobiol B-Biol 50: 149-158.

Chicaro P, Pinto E, Colepicolo P, Lopes JLC, Lopes NP 2004. Flavonoids from Lychnophora passerina (Asteraceae): potential antioxidants and UV-protectants. Biochem 
Syst Ecol 32: 239-243.

Dawczynski C, Schubert R, Jahreis G 2007. Amino acids, fatty acids, and dietary fibre in edible seaweed products. Food Chem 103: 891-899.

Fayaz M, Namitha KK, Murthy KNC, Swamy MM, Sarada R, Khanam S, Subbarao PV, Ravishankar GA 2005. Chemical composition, iron bioavailability, and antioxidant activity of Kappaphycus alvarezzi (Doty). $J$ Agric Food Chem 53: 792-797.

Gobbo-Neto L, Lopes NP 2007. Medicinal plants: Factors of influence on the content of secondary metabolites. Quim Nova 30: 374-381.

Gobbo-Neto L, Lopes NP 2008. Online identification of chlorogenic acids, sesquiterpene lactones, and flavonoids in the Brazilian arnica Lychnophora ericoides Mart. (Asteraceae) leaves by HPLC-DAD-MS and HPLCDAD-MS/MS and a validated HPLC-DAD method for their simultaneous analysis. J Agric Food Chem 56: 1193-1204.

Gressler V, Yokoya NS, Fujii MT, Colepicolo P, Mancini J, Torres RP, Pinto E 2010. Lipid, fatty acid, protein, amino acid and ash contents in four Brazilian red algae species. Food Chem 120: 585-590.

Gressler V, Fujii MT, Martins AP, Colepicolo P, Mancini J, Pinto E 2011. Biochemical composition of two red seaweed species grown on the Brazilian coast. J Sci Food Agric 91: 1687-1692.

Guaratini T, Vessecchi R, Pinto E, Colepicolo P, Lopes NP 2005. Balance of xanthophylls molecular and quasi-molecular ions in electrospray ionization. J Mass Spectrometry, 40: 963-968.

Guaratini T, Lopes NP, Pinto E, Colepicolo P, Gates P 2007. Differential Ionisation of Natural Antioxidant Polyenes in ESI and NanoESI Mass Spectrometry. Rapid Comm Mass Spectrom, 21: 3842-3848.

Guaratini T, Cardozo KHM, Pinto E, Colepicolo P 2009. Comparison of diode array and electrochemical detection in the $\mathrm{C}(30)$ reverse phase HPLC analysis of algae carotenoids. J Braz Chem Soc 20: 1609-1616.

Gutteridge JMC, Halliwell B 1990. The measurement and mechanism of lipid-peroxidation in biological-systems. Trends Biochem Sci 15: 129-135.

Holdt SL, Kraan S 2011. Bioactive compounds in seaweed: functional food applications and legislation. $J \mathrm{Appl}$ Phycol 23: 543-597.

Khotimchenko SV 2005. Lipids from the marine alga Gracilaria verrucosa. Chem Nat Compd 41: 285-288.

Nahas R, Abatis D, Anagnostopoulou MA, Kefalas P, Vagias C, Roussis V 2007. Radical-scavenging activity of Aegean Sea marine algae. Food Chem 102: 577-581.

Pellati F, Benvenuti S, Magro L, Melegari M, Soragni F 2004. Analysis of phenolic compounds and radical scavenging activity of Echinacea spp. J Pharm Biomed Anal 35: 289-301.

Pinto E, Carvalho AP, Cardozo KHM, Malcata FX, dos Anjos FM, Colepicolo P 2011. Effects of heavy metals and light levels on the biosynthesis of carotenoids and fatty acids in the macroalgae Gracilaria tenuistipitata (var. liui Zhang \& Xia). Rev Bras Farmacogn 21: 349-354.

Pinto E, Nieuwerburgh LV, Barros MP, Pedersén M, Colepicolo P, Snoeijs P 2003. Density-dependent patterns of thiamine and pigments in production in Nitzschia microcephala. Phytochemistry 63: 155-163.

Sánchez-Machado DI, López-Cervantes J, López-Hernández J, Paseiro-Losada P 2004. Fatty acids, total lipid, protein and ash contents of processed edible seaweeds. Food Chem 85: 439-444.

Sanina NM, Goncharova SN, Kostetsky EY 2004. Fatty acid composition of individual polar lipid classes from marine macrophytes. Phytochemistry 65: 721-730.

Yokozawa T, Chen CP, Dong E, Tanaka T, Nonaka G-I, Nishioka I 1998. Study on the inhibitory effect of tannins and flavonoids against the 1,1-diphenyl-2-picrylhydrazyl radical. Biochem Pharmacol 56: 213-222.

\section{*Correspondence}

Ernani Pinto

Departamento de Análises Clínicas e Toxicológicas, Faculdade de Ciências Farmacêuticas Universidade de São Paulo

Av. Professor Lineu Prestes, 580 05508-900 São Paulo-SP, Brazil

ernani@usp.br

Tel. +55113091 1505

Fax: +551130913661 